\title{
Author Correction: Roadmap for naming uncultivated Archaea and Bacteria
}

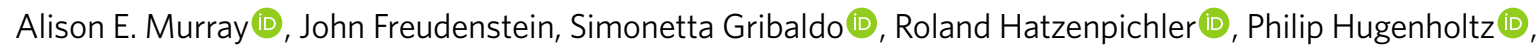
Peter Kämpfer, Konstantinos T. Konstantinidis, Christopher E. Lane (D), R. Thane Papke, Donovan H. Parks (D), Ramon Rossello-Mora, Matthew B. Stott 10 , lain C. Sutcliffe, J. Cameron Thrash (1D, Stephanus N. Venter, William B. Whitman, Silvia G. Acinas, Rudolf I. Amann, Karthik Anantharaman (1), Jean Armengaud (D, Brett J. Baker, Roman A. Barco, Helge B. Bode (D), Eric S. Boyd, Carrie L. Brady, Paul Carini, Patrick S. G. Chain, Daniel R. Colman, Kristen M. DeAngelis @ , Maria Asuncion de los Rios, Paulina Estrada-de los Santos @ , Christopher A. Dunlap, Jonathan A. Eisen (D), David Emerson, Thijs J. G. Ettema (D), Damien Eveillard (D), Peter R. Girguis, Ute Hentschel(D, James T. Hollibaugh, Laura A. Hug, William P. Inskeep (D), Elena P. Ivanova, Hans-Peter Klenk @D, Wen-Jun Li®, Karen G. Lloyd (D, Frank E. Löffler, Thulani P. Makhalanyane (D), Duane P. Moser, Takuro Nunoura (D, Marike Palmer (D, Victor Parro, Carlos Pedrós-Alió, Alexander J. Probst (D), Theo H. M. Smits (D), Andrew D. Steen (D), Emma T. Steenkamp, Anja Spang (1D, Frank J. Stewart, James M. Tiedje, Peter Vandamme, Michael Wagner, Feng-Ping Wang (D), Pablo Yarza, Brian P. Hedlund (1D and Anna-Louise Reysenbach (1D)

Correction to: Nature Microbiology https://doi.org/10.1038/s41564-020-0733-x, published online 8 June 2020.

In the version of this Consensus Statement originally published, Pablo Yarza was mistakenly not included in the author list. Also, in Supplementary Table 1, Alexander Jaffe was missing from the list of endorsees. These errors have now been corrected and the updated Supplementary Table 1 is available online.

\section{Additional information}

Supplementary information is available for this paper at https://doi.org/10.1038/s41564-020-00827-2.

(c) Open Access This article is licensed under a Creative Commons Attribution 4.0 International License, which permits use, sharing, adaptation, distribution and reproduction in any medium or format, as long as you give appropriate credit to the original author(s) and the source, provide a link to the Creative Commons license, and indicate if changes were made. The images or other third party material in this article are included in the article's Creative Commons license, unless indicated otherwise in a credit line to the material. If material is not included in the article's Creative Commons license and your intended use is not permitted by statutory regulation or exceeds the permitted use, you will need to obtain permission directly from the copyright holder. To view a copy of this license, visit http://creativecommons.org/licenses/ by/4.0/.

Published online: 12 November 2020

https://doi.org/10.1038/s41564-020-00827-2

(c) The Author(s) 2020 